\title{
K FUNKCII MOTÍVOV STROMU A VODY V ZBIERKE POHROMNICE LÝDIE VADKERTI-GAVORNÍKOVEJ
}

V debutovej zbierke Pohromnice (1966) Lýdie Vadkerti-Gavorníkovej je prítomný citlivý lyrický subjekt, ktorý je hlboko spriaznený s prírodou alebo naopak, príroda je vrastená do jeho bytia. $\mathrm{V}$ tomto príspevku sa budeme snažit' analyzovat' význam a funkciu motívov stromu a vody v uvedenej zbierke. Tieto motívy patria medzi ústredné v zbierke a objavujú sa takmer v každej básni. Pomocou analýzy básní sme zistili, že funkcia stromu je najčastejšie spomienka na otca, jeho stelesnenie, či duch, potom motív stromu je často spätý s niečím snovým alebo magickým, okrem toho môže predstavovat' minulost'. Na druhej strane motív vody je spojený s matkou, ale voda nepredstavuje stelesnenie matky, ale skôr je jej sprievodkyňou. Voda často predstavuje realitu, krutost' života a možno ju prepojit' aj so znázornením súčasnosti. Prostredníctvom týchto dvoch motívov je nepriamo podaná perspektíva a vzt’ah lyrického subjektu k rodičom a týmto spôsobom zároveň znázorňuje rodinné konflikty. Rodinná tematika je príznačná pre autorov Trnavskej skupiny, ku ktorým je často zarad'ovaná aj Vadkerti-Gavorníková.

Klúčové slová: Poézia, Trnavská skupina, motív stromu, motív vody, Lýdia VadkertiGavorníková.

The collection of poems Pohromnice (1966) was written by Lýdia Vadkerti-Gavorníková. The subject in this collection of poems is intertwined with nature. In this paper we analyze the meaning and function of the tree and water in collection of poems titled Pohromnice. These motifs are central and they appear in almost every poem. Through the analysis of poems, we found that the function of the tree most often represents a memory of the father, his embodiment, or spirit, also the motif of a tree is often associated with something dreamy or magical, and it cans also represent the past. On the other hand, the motif of water is associated with the mother, but water does not represent the embodiment of the mother, but rather it is her guide. Water often represents reality, the cruelty of life and can be linked to the depiction of the present. Through these two motifs the relationship of the lyrical subject with her parents and their family conflicts is indirectly represented. The theme of family is often explored by the writers of the Trnava Group to whom VadkertiGavorníková is often included.

Keywords: poetry, Trnava Group, tree motif, water motif, Lýdia Vadkerti-Gavorníková.

V roku 1966 Lýdia Vadkerti-Gavorníková debutovala zbierkou básní Pohromnice. Autorka bola v dotyku s poéziou Trnavskej skupiny, i ked'sa nezúčastnila zostavovania programu tejto skupiny, poetologicky mala k nim blízko a často bola aj zarad'ovaná ku konkretistom. Asociatívnost’ je jednou z významných čŕt jej poetiky, ktorá je zároveň bohatá na metafory (Čúzy a kol. 2006: 43). Do pôvodnej Trnavskej skupiny zarad’ujeme Jána Ondruša, Jána Stacha, Jozefa Mihalkoviča a L’ubomíra Feldeka, títo štyria básnici v roku 1958 vytvorili skupinové číslo časopisu Mladá tvorba. Podl'a Andrey Bokníkovej pojem konkretisti, bol vymyslený literárnou kritikou a zahŕňa ešte nasledovné mená: Jána Šimonoviča a Lýdiu Vadkertiovú. Konkretisti vytvorili 
osobitú poetiku, ktorou prenikli do hĺbky človeka s komplikovanou psychikou a neidylickými l'udskými vzt'ahmi. Snažili sa vnímat' skutočnost' všetkými zmyslami. L. Vadkertiová sa svojím debutom primkla ku konkretistom. Jej poézia sa zaoberala problematikou domova, do ktorej vniesla ženský svet. Medzi hlavné charakteristiky jej poézie možno zaradit' napojenie na tradíciu, spolu s tónom spovede. (Bokníková 2010: 32-34). Autorský subjekt je predovšetkým objektívom, zameraným na pozorovanie okolia a zobrazenie iných l'udí prostredníctvom ich rečového gesta (Bokníková 2004: 89). V našom príspevku budeme sledovat' motívy stromu, ale zároveň ajdreva či lesa, lebo sa navzájom prelínajú a ich funkcie. Podobne je to aj s motívom vody, ktorý sa tiež vyskytuje aj v obmenenej podobe ako rieka či potok.

Už v prvej básni zo zbierky Pohromnice sa stretávame s motívmi stromu a vody. V básni Stolárov dom lyrická subjektka spomína na otca ako umelca, ktorý dokáže svojou zručnost'ou vdýchnut' nový život drevu. Dôležité je podotknút', že obraz otca je $\mathrm{v}$ celej zbierke predstavený cez spomienky alebo cez prizmu detského pohl'adu. Drevo pripomína lyrickej subjektke nielen otca, ale aj detstvo. Akoby sa drevo, ktorého sa otec dotkol stávalo vznešeným a to nielen jeho výsledné dielo, ale aj všetky odpadové kúsky ako sú napr. piliny, či hoblinové špirály, ktoré sa potom vinú $\mathrm{k}$ hviezdam, čiže on dokáže vzkriesit', oživit' strom. Prostredníctvom pohybu nahor otec je stranscendentnený (Bokníková 2004: 89). Verš „Lístie v hrdle tajil kašlom pred matkou. "(Vadkerti-Gavorníková 2015: 7) naznačuje nielen otcov zlý zdravotný stav, ale aj vzt'ah otca a matky, v ktorom otec pred ňou skrýva závažný problém. Aj otcova smrt' je zobrazená pomocou dreva „Rozkvitalo drevo na márach“ (VadkertiGavorníková 2015: 7), čiže akoby aj po smrti dokázal pôsobit’ na drevo, alebo na nejaký spôsob bol spojený s ním. V nasledovnej strofe je obraz rieky, ktorá smúti (spolu s matkou a lyrickou subjektkou) a obraz matky naklonenou nad vodami. Tma a noc v poslednej strofe symbolizujú smútok lyrickej subjektky a v záverečnom verši je podaná paralela medzi otcom a drevom „Spomíname drevom na otca“ (VadkertiGavorníková 2015: 7). V poslednom verši nachádzame anakolút, ktorý je vel'mi častý v tvorbe Vadkerti-Gavorníkovej (Bokníková 2010: 38), pomocou neho autorka vytvorí neočakávanú štruktúru vety a tým spôsobom ozvláštňuje výpoved'. Zároveň prostredníctvom anakolútu autorka posilňuje význam motívu dreva a taktiež aj zintenzívni pocity, ktoré vyvolá u čitatel'a.

V básni Vel'ké st'ahovanie je opísaný jeden z kl'účových životných momentov pre lyrickú subjektku - st'ahovanie do nového domu, k otčimovi. Prvá čast' básne odkazuje na uplynulé cestovanie a starý domov; lyrická subjektka spomína na starú bránu, ktorý zanecháva, ulicu a zároveň aj na otca t. j. jeho opustený hrob „kde klíčil pomaly vžihl'ave kríz / otcovi na veku truhly. Ach, mama / verne zalieva / všetko, čo klići." (Vadkerti-Gavorníková 2015: 9). V týchto veršoch cítit' miernu iróniu voči matkinmu spôsobu vyrovnávania sa so stratou manžela alebo s faktom, že dokázala prekonat jeho smrt'. V nasledovných veršoch má matka ruky v potoku, čiže opät' je v styku s vodou. Prizma detského pohl'adu sa zameriava na matku, sníma ju ako materiálne starostlivú, cez gesto prania (Bokníková 2004: 89). V druhej časti básne motív vody je tiež v spojení s matkou, ona hl'adá vodu a následne varí večeru. V tretej časti je voda prítomná len implicitne prostredníctvom obrazu matky, ktorá pred pôrodom drhne, umýva dlážku.

Ešte jedno spomínanie na detstvo možno sledovat' v básni Fl'akatý mesiac. V noci akoby strom ožíval, vtedy dupne tak silno, až vyplaší studňu, dokonca aj vodu v ovo- 
cí, ktoré zreje. Zdá sa, že sa lyrická subjektka nachádza pod týmto stromom a počúva zvuk halúzky, dokonca cíti čo sa stáva v plodoch stromu, kým matka v kuchyni umýva riad a vie o niečom. Môžeme predpokladat', že vie o plači lyrickej subjektky pod stromom a vedomá si je jej smútku. K matke, ktorá umýva riad opät' možno priradit' vodu, zobrazenie každodenných pracovných úkonov, ale aj zmysel práce. Vzt'ah k matke je pohyblivý na ose míňanie sa - zbližovanie - ocenenie, kým vzt'ah k otcovi je vzt'ahom stabilnej transcendencie (Bokníková 2004: 90).

Napätie v rodinných vzt’ahoch je zachytené v básni Korene. Lyrická subjektka prichádza (už ako dospelá žena) k matke na návštevu. Hovoria o každodenných veciach, potom sa objaví obraz stromu, ktorý chodí pod oknom. Tento obraz na nás pôsobí ako náznak otcovej prítomnosti, akoby jeho duch bol na moment pri nich a počúval ich rozhovor. Nasleduje opät' motív stromu, lyrická subjektka sa pýta matky, či oskoruša rodí. Z nasledujúcich veršov vidno, že sa snažila zaviest' rozhovor iným smerom, lebo očakávala, že sa matka zmieni o otcovom vyrastaní, ktoré bolo spojené s oskorušou. Čakala, že matka vyrozpráva ako dedko „vyt’al $i$ nevyt’al / chlapca $i$ strom.“ (Vadkerti-Gavorníková 2015: 16), z čoho vidno, že lyrická subjektka pozná rodinné dejiny, žiada sa jej opät' počúvat' príbehy o otcovi, ale namiesto toho dostane iba výčitku, že sa odrodila. Osobné sebavymedzenie lyrickej subjektky a problém odtŕhania sa od dedinských koreňov je zretel'ný v celej zbierke (Bokníková 2004: 88), nielen $\mathrm{v}$ tejto básni. Vyčítame tu aj d’alšie rodinné súvislosti, napr. že je matka vhĺbená do seba, do vlastného smútku a pocitu opustenia, lebo jej dcéra nielen že odišla, ale sa aj odrodila. Vonku začne pršat' a matke sa ul'aví, lebo kým nespadne dážd' cíti sa akoby bola po kolená v potoku (odkazuje sa tým na matkin zdravotný stav, má problémy s bolest'ami a čoraz t’ažšie sa pohybuje). Verš „,Vstala a stôl ju podoprel“ (VadkertiGavorníková 2015: 17) naznačuje, že veci, ktoré vyrobil otec (stôl) nielenže pretrvávajú v čase, ale nosia v sebe určitú silu, niečo o čo sa vždy možno opriet' a na druhej strane, prostredníctvom tohto verša je ilustrovaná matkina choroba. Potom matka konštatuje, že rovno prší, toto je ojedinelý príklad, že voda má negatívnu konotáciu: „Takáto voda pozatíka / úrodu pod korene.“ (Vadkerti-Gavorníková 2015: 17). Motív vody je aj tu spojený s motívom matky akoby u Vadkerti-Gavorníkovej tieto dva motívy stále patrili k sebe. Predchádzajúci verš by sme mohli interpretovat’aj nasledovne: voda spôsobuje zánik života, ktorý nestačil preniknút' na povrch a zatláča ho niekde pod vlastné korene. Pri odchode, za lyrickou subjektkou sa nachádza obraz stromu, ktorý môžeme chápat' aj ako symbol jej otca, ktorý za súmraku odprevádza svoju dcéru (predpokladáme, že matka už nemá sily ju odprevadit').

Názov básne Popolec sa vzt’ahuje na posvätný popol, ktorý sa používa pri bohoslužbe (v rámci katolíckej cirkvi) na Popolcovú stredu. Tento popol pre mnohých krest’anov predstavuje pripomienku konečnosti života: ,... pretože si prach / a do prachu sa vrátišs، (Biblia 1999: 13). Báseň je spomínanie lyrickej subjektky na rozhovor s niekým počas ich cesty (predpokladáme, že je to cesta z kostola alebo do kostola), ktorá vedie vedl'a rieky. Rozprávali sa o vode „a o tom, ako v predjarí / spomína rieka na pol chotára / bývalé more." (Vadkerti-Gavorníková 2015: 27). Spomínanie rieky v tomto verši možno interpretovat' ako šumenie rieky t. j. ako jej hlas, ktorým hovorí o mori, ale na druhej strane sloveso spomína môže predstavovat' rozpomínanie sa človeka na more, pri pohl'ade na mohutnú rieku. Vedl'a rieky je aj strom, ktorý onedlho rozkvitne, predstavuje zrod nového života, akoby odškodnenie za straty, 
ktoré sa udiali počas zimy (smrt' mladého chlapca). Nadväzovanie na l'udovú tradíciu je viditel'né aj z verša „Teda nedokončíšs / skôr, ako začnešs.“ (Vadkerti-Gavorníková 2015: 27), ktorý pripomína porekadlo, múdrost’ anonymného autora, ktorá bola následne ústne tradovaná. Spolu hovorili aj o chlapcovi, ktorý zahynul a v zime ho „lovili tri dni na dne lúk." (Vadkerti-Gavorníková 2015: 27), čo je zintenzívnené prekvapivým spojením - metaforou - dno lúk, (namiesto očakávaného dna vody alebo rieky). Spolubesedník nakoniec konštatuje, že „Voda v predjarí / je iba roztopený sneh." (Vadkerti-Gavorníková 2015: 28), z čoho možno uvažovat' o cyklickosti vody a zároveň aj života, kým na druhej strane častica iba môže naznačovat' pokus hovorcu poukázat' na bežnost' vody, zmazat' z nej rúcho mystickosti, aké lyrická subjektka pravdepodobne cíti pri kontakte s ňou.

Báseň Leto pod Chmúrou je rozdelená do troch celkov; prvý celok sa viaže na budúcnost', druhý na prítomnost' a tretí na minulost'. Lyrická subjektka prichádza v daždi, akoby prichádzala so smútkom. Predstavuje si les, po ktorom sa bude prechádzat', bude tam aj prameň a strmina, na ktorej je prevrátený strom, na jeho koreňoch je slané ovocie. V druhej časti vo verši „Posledný strom opúšta okraj lesa.“ (VadkertiGavorníková 2015: 32) máme obraz postupného stmievania sa, stromy v lese sa už nemôžu vidiet', priam sa zdá, že ho opúšt’ajú. Lyrická subjektka je v prírode a komunikuje s drevom, trávou a kameňom, ktoré charakterizuje ako teplé, príjemné, drevo pre ňu bude vždy predsavovat' istotu a teplo domova. Potok prelamuje vodu ,cez skamenené kolená" (Vadkerti-Gavorníková 2015: 33). Tento obraz možno vnímat' ako prenesenie situácie z prírody, ale skamenené kolená vody by mohli naznačovat', že je voda (ako) stará (žena). Lyrická subjektka sa stotožňuje s celým lesom, lebo podobne ako on aj ona sa zloží sama. Na druhej strane dostane sa k náručiu vody, ale aj tento akt blízkosti a prepojenosti je na úver, čiže akoby sa voči vode vždy cítila byt' zaviazaná. V tretej časti lyrická subjektka odchádza v slnku, znamená to, že pod Chmúrou našla určitý pokoj, po ktorom túžila, akoby ju les upokojil. Spomína na potok a akoby ju upokojoval fakt, že stále niekde žijú a vznikajú nové pramene.

V básni $O$ lese je dominantný motív stromov. Na začiatku básne je predstavené ticho a pokoj, ktoré panujú lesom. Zároveň veršom „Strom ustupuje stromu“ (VadkertiGavorníková 2015: 37) je vystihnutá podstata spolužitia v prírode. V d’alšej strofe sa objavujú predmety, ktoré nepatria do lesa, sú predzvest'ou niečoho negatívneho. Nasleduje príchod drevorubačov, ktorí, zdá sa, svojimi krokmi kolíšu celú zem a týmto spôsobom rušia pokoj v lese. Ich činnost'ou sa priestor mení a zvalené stromy pripomínajú hromadné popravisko. Ale l'udské konanie sa neobíde bez obetí, niekoho počas rúbania privalí a tým spôsobom príroda ukáže svoju silu voči l'ud'om. Posledné verše básne: „Les ako popísaná strana. / Bodka / Otáznik “ (Vadkerti-Gavorníková 2015: 38) na jednej strane môžeme interpretovat' tak, že priestor čiastočne vyrúbaného lesa pripomína popísanú stranu alebo aj samé písanie a tematizovanie lesa v autorkinej tvorbe, kým na druhej strane by sme mohli tieto verše interpretovat' ako „prevtelenie sa“ lesa t. j. stromu do papiera. Otáznik v poslednom verši môže signalizovat' problematiku obetovania lesov na l'udské potreby.

V básni Sen so synom syn zo sna sa zjavujú dva naratívne postupy, ktoré sa navzájom prelínajú, jeden sa vzt'ahuje na budúcnost', oslovuje syna a pôsobí ako predzvest', kým sa druhý naratívny postup vzt’ahuje na minulost' a obsahuje spomínanie (na sen). Aj v tejto básni sú výrazné motívy stromu a vody, napr. vo veršoch: „Zabúšiš vode na 
dvere, otvorí / hmatu, v koreňoch odzrkadlí strom. " (Vadkerti-Gavorníková 2015: 55) oslovuje sa syn, ktorý akoby komunikoval s vodou, ktorá mu zároveň naznačuje, že $\mathrm{v}$ jeho koreňoch, jeho základoch, jeho podstate je strom. Mohlo by sa to interpretovat' aj v tom zmysle, že jej syn nesie v sebe niečo po jej otcovi (stolárovi). Pokúša sa vstúpit' do sveta, ale ešte „Nedočiahol / breh, a strom s naklonenou / obetnou miskou oviala bolest'.“ (Vadkerti-Gavorníková 2015: 55-56). Ďalej hovorí synovi, že jeho krok bude v dotyku s vodou, čiže dáva mu znalost' o tom, že bude s ňou stále spriaznený. Nasleduje obraz prvej vlny, ktorá zaplavila brehy, kým krvácal strom a „do podušiek prstov / vyleptal nesúmerný / krúživý tep." (Vadkerti-Gavorníková 2015: 57). Strom svojím utrpením formuje odtlačky na prstoch, akoby vytváral niečiu osobitost'. Následne sa syn obzerá za vodou, akoby sa s ňou lúčil. Druhá vlna zhodila obetnú misku do tmy. Posledná, tretia vlna na breh vylodila syna, čiže syn sa dostáva na pevninu - narodil sa, tentoraz dočiahne breh a svoj palec s ,letokruhom“ odtlačil na prah domu. Syn sa konečne dostáva k matke, je pri nej a potom nasleduje obraz stromov, ktoré sa cez komíny dostávajú k nebu, čiže strom nie je len prírodný objekt, ale je aj symbolom, ktorý sa vzt’ahuje na otca (stolára) a určitú sakrálnost' a mystickost' voči jeho bytiu.

Častý výskyt motívov stromu (dreva, lesa) a vody (potoka, rieky) v debute Lýdie Vadkerti-Gavorníkovej odkazuje na ich dôležitost' a autorka im prisudzuje viaceré významy, respektíve funkcie. Strom je často spomienkou na otca (predstavuje minulost'), reprezentuje otcovo stelesnenie, či duch a manifestuje teplo domova a stabilitu, napr. teplé veci ako sú drevo, tráva, kameň v básni Leto pod Chmúrou (VadkertiGavorníková 2015: 32). Strom zastupuje aj umenie - stolárove (otcove) výtvory sú aj umelecké diela, otec lyrickej subjektke odovzdal cit a nehu voči prírode a umeniu. Motív stromu signalizuje aj jednotnost' prírodného a l'udského, najčastejšie prostredníctvom personifikácií: dupol strom v básni Fl'akatý mesiac (Vadkerti-Gavorníková 2015: 13), strom ustúpi stromu v básni O lese (Vadkerti-Gavorníková 2015: 37), d’alej v básní Sen so synom syn zo sna strom krvácal, strom vystielal hniezda vode a slnku (Vadkerti-Gavorníková 2015: 57-58); prípadne les ako obet' l'udského pôsobenia - vyklčovanie lesa v básni $O$ lese. Strom symbolizuje spätost' s niečím snovým alebo magickým, napr. v básni Stolárov dom sú to hoblinové špirály, ktoré sa vinú ku hviezdam (Vadkerti-Gavorníková 2015: 7), v básni Sen so synom syn zo sna syn má palec s ,letokruhom“ - v sebe nosí niečo po stolárovi, dedovi (Vadkerti-Gavorníková 2015: 58). Ked’ ide o motív vody (potoka, rieky) on je najčastejšie spojený s matkou. Voda nepredstavuje stelesnenie matky, ale skôr je jej sprievodkyňou. Niekedy zastupuje realitu alebo krutost' života, ako napr. smutná rieka v básni Stolárov dom (Vadkerti-Gavorníková 2015: 7), alebo ked' sa hovorí, že voda pozatíka úrodu v básni Korene (Vadkerti-Gavorníková 2015: 18), či že je náručie vody na úver (VadkertiGavorníková 2015: 33) v básni Leto pod Chmúrou. Motív vody pritom odkazuje aj na súčasnost', každodenné pracovné úkony a vyzdvihuje zmysel práce, napr. matka umýva riad v básni Fl'akatý mesiac (Vadkerti-Gavorníková 2015: 13), matka má ruky v potoku, alebo hl'adá vodu, aby navarila večeru v básni Vel'ké st'ahovanie (VadkertiGavorníková 2015: 9-10). Nakoniec v básni Sen so synom syn zo sna voda reprezentuje spriaznenost' človeka s vodu - jej (a synov) krok bude v dotyku s vodou - je to implicitné prepojenie so starou matkou (Vadkerti-Gavorníková 2015: 56). 


\section{Citovaná literatúra}

Biblia, Písmo Sväté Starej a Novej zmluvy. Liptovský Mikuláš: Tranoscius, 1999.

Bokníková, Andrea. „Lýdia Vadkerti-Gavorníková“. [V:] J. Burianová (red.) Portréty slovenských spisovatel'ov 1. Bratislava: Univerzita Komenského, 2004, 87-96.

Bokníková, Andrea. „K osudom a najmä k prínosom Trnavskej skupiny-konkretistov“. Eslavística Complutense, 10, 2010: 31-55.

Čúzy, Ladislav, Darovec, Peter, Hochel, Igor, Kákošová, Zuzana. Panoráma slovenskej literatúry III. Bratislava: Slovenské pedagogické nakladtel'stvo, 2006.

Vadkerti-Gavorníková, L. Pohromnice. Košice: Európsky dom poézie Košice, 2015.

\section{Jana Domoniová}

\section{FUNKCIJA MOTIVA DRVETA I VODE U ZBIRCI PESAMA POHROMNICE LIDIJE VADKERTI-GAVORNJIKOVE}

\section{Rezime}

Ovaj rad je usmeren na analizu motiva drveta i vode tj. na njihovo značenje i funkciju u zbirci pesama Pohromnice Lidije Vadkerti-Gavornjikove. Analizom pesama smo saznali da motiv drveta predstavlja sećanje na oca, njegovo otelotvorenje ili njegov duh. Često je povezan i sa prošlošću i detinjstvom. Drvo simboliše toplinu doma i određeni vid stabilnosti, osim toga predstavlja jedinstvo prirode i čoveka. Ovaj motiv se takođe spaja sa nečim magijskim, kao i sa umetnošću. Sa druge strane, motiv vode je povezan sa majkom, ali u ovom slučaju voda ne predstavlja otelotvorenje majke, već element koji je prati. Voda može predstavljati realnost, ili okrutnost života. Ilustruje sadašnjost, svakodnevne radnje i ističe smisao rada. Pomoću pomenuta dva motiva ilustruju se porodični odnosi, kao i odnos lirskog subjekta prema svojim roditeljima. Porodične teme su karakteristične za autore Trnavske grupe, među koje se ubraja i Lidija Vadkerti-Gavornjikova.

Ključne reči: poezija, Trnavska grupa, motiv drveta, motiv vode, Lidija Vadkerti-Gavornjikova. 